\title{
Toxicity of Dimorphandra mollis to Workers of Apis mellifera
}

\author{
Priscila Cintra $^{b}$, Osmar Malaspina ${ }^{b}$ Fernando Petacci $^{a}$, João B. Fernandes ${ }^{a *}$, Odair C. Bueno $^{b}$, \\ Paulo C. Vieira and M. Fátima das G. F. da Silva ${ }^{a}$ \\ ${ }^{a}$ Departamento de Química, Universidade Federal de São Carlos, CP 676, 13565-905, São Carlos - SP, Brazil \\ ${ }^{b}$ Centro de Estudos Insetos Sociais, Instituto de Biociências, Universidade Estadual Paulista, Campus Rio Claro, \\ Av. 24-A, 1515, 13506-900, Rio Claro - SP, Brazil
}

\begin{abstract}
Nesta comunicação estamos reportando as propriedades tóxicas dos extratos metanólicos das flores, pedúnculos, folhas, pecíolo e casca do tronco de Dimorphandra mollis sobre as operárias de Apis mellifera. Astilbina (3- $\beta$-O-rhamnosideo de 5,7,3',4'- tetraidroxi-2,3-diidroflavonol) isolada dos pedúnculos e flores como o seu principal componente, apresentou atividade inseticida sobre abelhas confinadas. Os resultados obtidos indicam que a astilbina reduz a sobrevivência média das abelhas tratadas.
\end{abstract}

In this communication we have evaluated the toxic properties of methanol extracts from flowers, peduncles, leaves, petioles and stem bark of Dimorphandra mollis to Apis mellifera workers. Astilbin (5,7,3',4'-tetrahydroxy-2,3-dihydroflavonol-3- $\beta$-O-rhamnoside) has been isolated from peduncles and flowers of this plant in large amounts. Astilbin presented insecticidal activity against confined bees. The results suggest that astilbin reduces the average survival of treated bees.

Keywords: flavonoids, natural insecticides, Dimorphandra mollis, Apis mellifera

\section{Introduction}

Dimorphandra mollis Benth. (Fabaceae, Caesalpinioideae $)^{1}$ is a very common tree that occurs from south to west in Brazil. There are no references about the occurrence of this species in other parts of the world. Two plant species have been popularly known as "barbatimão": Stryphnodendron adstringens (true "barbatimão") and Dimorphandra mollis (false "barbatimão"). ${ }^{1}$ In spite of belonging to different genera, both species are sympatric (similar blooming period), from September to January, and the pollen of Stryphnodendron polyphyllum has been reported to be toxic to bees. ${ }^{2}$

Considering that while plants produce substances attractive to bees, they need to protect other parts, as well as flower bud, generally the place where bees collect substances to make propolis, from herbivore attack. This defense is commonly made by repellents, deterrents or even by toxic chemical compounds. ${ }^{3}$

Field observations by Brazilian beekeepers revealed that $D$. mollis is toxic to bees during blooming season. The aim of this study is to evaluate the toxicity of the

\footnotetext{
*e-mail: djbf@power.ufscar.br
}

compounds isolated from flowers, peduncles, leaves, petioles and stem bark of $D$. mollis against workers of $A$. mellifera.

\section{Results and Discussion}

Dichloromethane and methanol extracts of flowers, peduncles, leaves, petioles and stem bark, were prepared (Table 1) and tested in toxic bioassays against bees, applying a sucrose and honey diet of $30 \mathrm{mg}$ per bee,

Table 1. Weigh of dichloromethane and methanolic extracts of peduncles, petioles, leaves, stem bark and flowers of Dimorphandra mollis and concentration of 1-3 in each extract and dry material.

\begin{tabular}{lrcccc}
\hline Plant parts & \multicolumn{2}{c}{ Extracts } & \multicolumn{2}{c}{$\begin{array}{c}\text { in relation to methanol } \\
\text { extract/ }\end{array}$} \\
& \multicolumn{1}{c}{$\mathrm{CH}_{2} \mathrm{Cl}_{2}$} \\
& $(\mathrm{~g})$ & $\begin{array}{c}\mathrm{CH}_{3} \mathrm{OH} \\
(\mathrm{g})\end{array}$ & $\mathbf{1}$ & $\mathbf{2}$ & $\mathbf{3}$ \\
& 2.9 & 16.3 & $99.9 / 10.1$ & $\mathrm{Nd}$ & $\mathrm{Nd}$ \\
Peduncles & 4.7 & 15.8 & $\mathrm{Nd}$ & $\mathrm{Nd}$ & $\mathrm{Nd}$ \\
Petioles & 17.9 & 30.0 & $\mathrm{Nd}$ & $\mathrm{Nd}$ & $\mathrm{Nd}$ \\
Leaves & 1.8 & 25.2 & $60.6 / 2.5$ & $16.6 / 0.7$ & $9.0 / 0.4$ \\
Stem bark & 7.5 & 34.1 & $99 / 7.6$ & $\mathrm{Nd}$ & $\mathrm{Nd}$ \\
Flowers & & & & &
\end{tabular}

$\mathrm{Nd}=$ not detected, 
containing 1.0, 0.5 and. $0.2 \%$ of these extracts or pure astilbin. Bioassays with dichloromethane and methanol extracts from leaves and petioles showed no activity. The methanol extracts of flowers, part of the plant highly visited by the bees, and also the extracts of peduncles and stem bark were actives (Figure 1, Table 2). After twelve days for the high concentrated flowers and peduncles extracts tested all the bees died, while in the control the workers
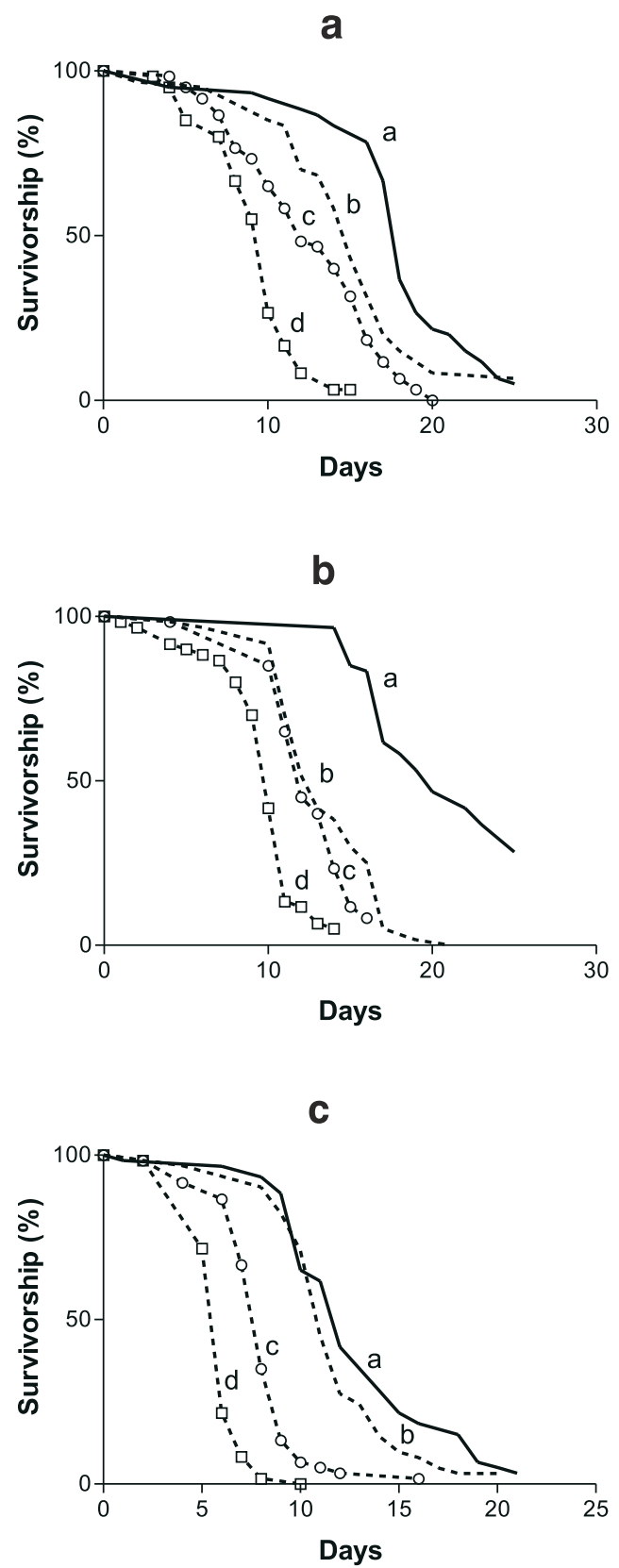

Figure 1. Survivorship curves of A. mellifera for ingestion experiments of: a peduncles methanol extract (astilbin 99.9\%, $\chi^{2}=98.93 ; \mathrm{p}<0.0001$ ), b flowers methanol extract (astilbin 99\%, $\left.\chi^{2}=128.9 ; \mathrm{p}<0.0001\right)$, c stem bark methanol extract $\left(\chi^{2}=164.2\right.$; $\mathrm{p}<0.0001)$ from D. mollis. - Control, --- $0.2 \%$, ---०---०--- 0.5\%, ---口---口--- 1.0\%. Letter different of a indicates significant difference between the control and experimental treatment. died after 22-25 days. The methanol extract from the stem bark showed to be active, killing all the bees within 8 days. The toxic bioassays were accomplished by Log Rank test ${ }^{4}$ and all active test had $\mathrm{p}<0.0001$.

From the methanol extracts of peduncles and flowers, astilbin (1) was isolated (crystallization from methanol/ hexane, 1:1) as a major component (its concentration is higher than $99 \%$ in this extract), while the methanol extracts of the stem bark afforded mixture of astilbin, as the major constituent $(60.6 \%)$, neoisoastilbin $(2,16.6 \%)$ and catechin $(\mathbf{3}, 9.0 \%)$. These compounds were identified by comparison of their spectral data with those in the literature for astilbin, ${ }^{5}$ neoisoastilbin ${ }^{5}$ and catechin. ${ }^{6,7}$

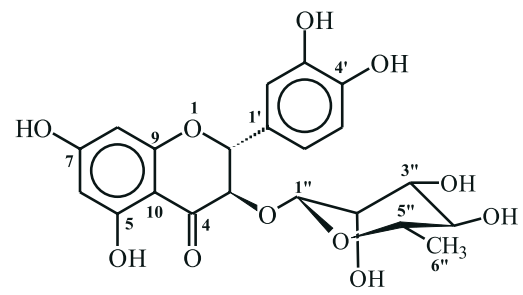

1<smiles>CC1C(O)C(O)C(OC2C(=O)c3c(O)cc(O)cc3O[C@@H]2c2ccc(O)c(O)c2)C(O)C1O</smiles>

2<smiles>Oc1cc(O)c2c(c1)O[C@H](c1ccc(O)c(O)c1)C(O)C2</smiles>

3

Table 2. $\chi^{2}$ and $\mathrm{p}$ of the control survivorship curves and of different concentrations curves.

\begin{tabular}{ccrr}
\hline $\begin{array}{c}\text { Survivorship } \\
\text { curves }\end{array}$ & $\begin{array}{c}\text { Concentration } \\
(\mathrm{c}, \%)\end{array}$ & $\chi^{2}$ & $\mathrm{p}$ \\
\hline $\mathbf{A}$ & 0.2 & 11.05 & 0.0009 \\
& 0.5 & 45.91 & $<0.0001$ \\
& 1.0 & 89.64 & $<0.0001$ \\
$\mathbf{B}$ & 0.2 & 72.68 & $<0.0001$ \\
& 0.5 & 88.40 & $<0.0001$ \\
& 1.0 & 115.20 & $<0.0001$ \\
$\mathbf{C}$ & 0.2 & 3.89 & 0.0484 \\
& 0.5 & 60.82 & $<0.0001$ \\
& 1.0 & 115.20 & $<0.0001$ \\
\hline
\end{tabular}


The lethality bioassay to the bees with astilbin showed the same activity as that of the peduncles methanol extract containing $99.9 \%$ of 1 (Figure 1, Table 2). Surprisingly the stem bark methanol extract was highly active (Figure 1, Table 2), therefore separate bioassays with neoisoastilbin and catechin will be necessary to confirm the activity of each component of the mixture and if there is a synergism between them, and to determine whether $\mathbf{2}$ or $\mathbf{3}$ is more active than $\mathbf{1}$. However, since astilbin is the major component in all active extracts analyzed, it could be responsible for the main observed activity of $D$. mollis against workers of A. mellifera.

Previous work with Lonchocarpus speciosus extracts, containing astilbin in mixture with others flavonoids, showed insecticidal effects against Drosophila melonogaster flies. ${ }^{8}$ Astilbin exhibits a variety of other biological activities such as reducing total liver cholesterol concentration, ${ }^{9}$ protecting against oxidative damage to liver mitochondria and hemolysis erytrocytes, ${ }^{10}$ inhibiting lens aldose reductase to prevent cataract formation in diabetes,${ }^{11}$ enhancement of the vanadate-stimulated release of lipoprotein lipase activity, ${ }^{12}$ and hepatoprotective effect in rats ${ }^{13}$ and mices. ${ }^{14}$

\section{Experimental}

\section{Plant material}

The flower peduncles $(161 \mathrm{~g})$, petioles $(220 \mathrm{~g})$, leaves $(650 \mathrm{~g})$, stems bark $(600 \mathrm{~g})$ and flowers $(450 \mathrm{~g})$ of D. mollis were collected in Rio Claro, São Paulo state Brazil, in February of 1999. These parts were dried separately in a stove with air circulation $\left(40^{\circ} \mathrm{C}\right)$ and milled in a Willey mill type.

\section{Extraction and isolation of the chemical constituents}

The extraction of the plant material was performed with dichloromethane (3 times) followed by methanol (2 times). The amount of solvent used each time in the extraction of the dry material were $0,5 \mathrm{~L}$ for peduncles and petioles; $1,0 \mathrm{~L}$ for flowers and 1,5 $\mathrm{L}$ for leaves and stem bark.

Catechin $(17.1 \mathrm{mg})$ and the mixture of astilbin and neoisoastilbin $(160.5 \mathrm{mg})$ were separated by preparative flash chromatography from part of methanol extract of stem bark $(190 \mathrm{mg})$. The mixture of astilbin and neoisoastilbin (25 mg) was submitted to recycling HPLC separation on a polymeric packing column (Shimadzu, Asahipak GS-310 P, $21.5 \mathrm{~cm} \mathrm{ID} \mathrm{x} 50.0 \mathrm{~cm} \mathrm{~L}$ ) eluted with $\mathrm{MeOH}$ (Flow rate: $7 \mathrm{~mL} \mathrm{~min}{ }^{-1} \mathrm{UV}$ detector at $290 \mathrm{~nm}$ ) yielding astilbin $(18 \mathrm{mg})$, neoisoastilbin $(5 \mathrm{mg})$, after five cycles of $30 \mathrm{~min}$.
Biological assay

Africanized bees Apis mellifera were collected at the UNESP- Rio Claro apiary. Newly emerged bees were identified on the basis of their color and collected. All bees used for the experiments had the same age.

The extracts or astilbin were incorporated in small percentages $(0.2 \%, 0.5 \%$ and $1 \%)$ to the bees artificial diet. The diet consisted of sucrose and honey (5:1) and was given as such to the control group. The diet was offered to sixty bees divided into three groups of twenty bees confined in small cages $(11 \mathrm{~cm} \mathrm{X} 11 \mathrm{~cm} \mathrm{X} 7 \mathrm{~cm})$. For a higher survival average the bees were confined in groups of twenty. ${ }^{15}$ The control group received just the diet and water daily. The experiments were performed during 25 days, at $32^{\circ} \mathrm{C}$, in a BOD apparatus and the number of dead bees was registered.

The daily survival rates for each treatment was calculated and the survival curves were traced using the Software Graphpad Prism 2.01. The non-parametric test of Log Rank ${ }^{4}$ was applied a posteriori, to compare each treatment with the control group.

Astilbin (1): ${ }^{1} \mathrm{H}$ NMR $\left(200 \mathrm{MHz}, \mathrm{CD}_{3} \mathrm{OD}\right) \delta 5.20$ (d, $J$ $10 \mathrm{~Hz}, 1 \mathrm{H}, \mathrm{H}-2), 4.60$ (d, J $10 \mathrm{~Hz}, 1 \mathrm{H}, \mathrm{H}-3), 5.85$ (d, J 2.0 $\mathrm{Hz}, 1 \mathrm{H}, \mathrm{H}-6$ ), 5.86 (d, J 2.0 Hz, $1 \mathrm{H}, \mathrm{H}-8$ ), 6.87 (br s, $1 \mathrm{H}, \mathrm{H}-$ 2'), 6.70-6.75 (m, 2 H, H-5' and 6'), 4.05 (br s, $1 \mathrm{H}, \mathrm{H}-1$ '), 3.34 (m, 1H, H-2"), 3.20 (m, 1H, H-3"), 3.12 (m, 1H, H-4"), 3.91 (m, $1 \mathrm{H}, \mathrm{H}-5$ "), 1.10 (d, J $6.0 \mathrm{~Hz}, 3 \mathrm{H}, \mathrm{H}-6$ "); ${ }^{13} \mathrm{C}$ NMR $\left(50 \mathrm{MHz}, \mathrm{CD}_{3} \mathrm{OD}\right) \delta 84.7$ (C-2), 79.3 (C-3), $196.8(\mathrm{C}-4)$, 166.3 (C-5), 98.2 (C-6), 169.3 (C-7), 97.1 (C-8), 164.9 (C9), 103.2 (C-10 e C-1"), 130.0 (C-1'), 117.1 (C-2'), 147.3 (C-3'), 148.1 (C-4'), 116.2 (C-5'), 121.3 (C-6'), 102.9 (C1"), 72.6 (C-2"), 73.2 (C-3”), 74.6 (C-4”), 71.3 (C-5”), 18.7 (C-6"),

Neoisoastilbin (2): ${ }^{1} \mathrm{H}$ NMR (200 MHz, $\left.\mathrm{CD}_{3} \mathrm{OD}\right)$ $\delta 5.50(\mathrm{~d}, J 2.5 \mathrm{~Hz}, 1 \mathrm{H}, \mathrm{H}-2), 4.20(\mathrm{~d}, J 2.5 \mathrm{~Hz}, 1 \mathrm{H}, \mathrm{H}-3), 5.86$ (d, J2.0 Hz, 1H, H-6), 5.90 (d, J2.0 Hz, 1H, H-8), 6.84 (br s, 1H, H-2'), 6.70-6.75 (m, 2H, H-5' and 6'), 4.78 (br s, 1H, H1"), 3.45 (m, 1H, H-2"), 3.40 (m, 1H, H-3"), 3.02 (t, J9.0, 1H, H-4"), 2.42 (m, 1H, H-5"), 0.83 (d, J $6.0 \mathrm{~Hz}, 3 \mathrm{H}, \mathrm{H}-6$ "); ${ }^{13} \mathrm{C}$ NMR (50 MHz, CD OD) $\delta 82.0$ (C-2), 76.9 (C-3), 194.1 (C4), 166.2 (C-5), 97.6 (C-6), 169.8 (C-7), 96.5 (C-8), 164.5 (C-9), 101.6 (C-10), 128.6 (C-1'), 116.3 (C-2'), 146.5 (C-3'), 146.6 (C-4'), 115.3 (C-5'), 119.4 (C-6'), 102.0 (C-1'), 72.0 (C-2" e C-3"), 73.4 (C-4"), 70.8 (C-5"), 17.8 (C-6").

Catechin (3): ${ }^{1} \mathrm{H}$ NMR $\left(200 \mathrm{MHz}, \mathrm{CD}_{3} \mathrm{OD}\right) \delta 3.88(\mathrm{~m}$, $1 \mathrm{H}, \mathrm{H}-3), 2.40$ (dd, $J 16.0$ and $8.0 \mathrm{~Hz}, 1 \mathrm{H}, \mathrm{H}-4), 2.75$ (dd, $J$ 16.0 and $5.4 \mathrm{~Hz}, 1 \mathrm{H}, \mathrm{H}-4), 5.75(\mathrm{~d}, J 2.2 \mathrm{~Hz}, 1 \mathrm{H}, \mathrm{H}-6), 5.78$ (d, J2.2 Hz, 1H, H-8), 6.74 (br s, 1H, H 2'), 6.71 (m, 2H, H $\left.5^{\prime}, 6^{\prime}\right) ;{ }^{13} \mathrm{C}$ NMR $\left(50 \mathrm{MHz}, \mathrm{CD}_{3} \mathrm{OD}\right) \delta 84.1(\mathrm{C}-2), 70.1$ (C3), 29.0 (C-4), 156.3 (C-5), 97.5 (C-6), 156.9 (C-7). 96.8 
(C-8), 156.7 (C-9), 133.2 (C-1'), 116.5 (C-2'), 146.5 (C-3', 4'), $117.3(\mathrm{C}-5$ '), 121.3 (C-6').

\section{Acknowledgment}

The authors would like to thank the CNPq (Conselho Nacional de Desenvolvimento Científico e Tecnológico), Coordenação de Pessoal de Nível Superior (CAPES), PRONEX/MCT-FINEP, and Fundação de Amparo à Pesquisa do Estado de São Paulo (FAPESP), for the financial support and scholarships (CNPq).

\section{References}

1. Lorenzi, H.; Árvores Brasileiras: manual de identificação e cultivo de plantas arbóreas nativas do Brasil. Editora Plantarum, Nova Odessa, SP., 1992.

2. Carvalho, A. C. P.; Message, D.; Campos, L. A. O.; Batrh, M.; Marco Júnior, P.; Anais Encontro Sobre Abelhas, Ribeirão Preto. Brazil, 1998, p. 3.

3. Harborne, J. B. In Introduction to Ecological Biochemistry; Academic Press, London, 3th. ed., 1988, p. 356.

4. Motulsky, M.D.H. In Intuitive Biostatistics; Oxford University Press, New York, 1995, p. 386.

5. De Brito, J.; Manickam, V. S.; Gopalakrishnan, S.; Ushioda, T.; Tanaka, N.; Chem. Pharm. Bull. 1995, 43, 338.
6. Agrawal, P. K.; Carbon-13 NMR of Flavonoids, Elsevier Sc. Publishers, Amsterdam, 1989, p. 444.

7. Ho, C.-T.; Chen, Y.; Wang, M.; Rosen, R. T.; J. Agric. Food Chem. 1999, 47, 2226.

8. El Sayed, N.H.; Soher, E.A.; Masoud, R.A.; Mabry, T.J.; Asian J. Chem. 1997, 9, 738.

9. Igarashi, K.; Uchida, Y.; Murakami, N; Mizutani, K.; Masuda, H.; Biosc. Biotech. Biochem. 1996, 60, 513.

10. Haraguchi, H.; Mochida, Y.; Sakai, S.; Masuda, H.; Tamura, Y.; Mizutani, K; Tanaka, O.; Chou, W.-H.; Biosc. Biotech. Biochem. 1996, 60, 945.

11. Haraguchi, H.; Ohmi, I.; Masuda, H.; Tamura, Y.; Mizutani, K; Tanaka, O.; Chou, W.-H.; Experientia 1996, 52, 564.

12. Motoyashiki, T.; Miyake, M.; Morita, T.; Mizutani, K.; Masuda, H.; Ueki, H.; Biol. Pharm. Bull. 1998, 21, 517

13. Closa, D.; Torres, M.; Hotter, G.; Bioque, G.; Leon, O.S.; Gelpi, E.; Rosello Catafau, J.; Prostaglandins Leukotrienes and Ess. Fatty Acids 1997, 56, 331.

14. Xu, Q.; Wu, F.G.; Cao, J.S.; Chen, T.; Jiang, J.Y.; Saiki, I.; Koda, A.; Europ. J. Pharm. 1999, 377, 93.

15. Betioli, J. V.; MSc Thesis, Universidade Estadual Paulista, Campus of Rio Claro, Brazil, 1989, p. 74.

Received: July 24, 2000

Published on the web: December 10, 2001

FAPESP helped in meeting the publication costs of this article. 